\title{
Web-Based Student Project Management System: A Tetfund Institution- Based Research Report
}

\author{
Ugboaja Uchenna Chikwendu ${ }^{1}$, Eziechina Malachy Amaechi ${ }^{2}$ \\ ${ }^{1,2}$ Department of Computer Science Akanu Ibiam Federal Polytechnic, Unwana
}

\begin{abstract}
Students' final year projects are often characterized by poor quality, duplication of existing works, prolonged research writing and late submission. This TetFund sponsored research project: Web-based Student Project Management System, is designed with the latest technologies to mitigate these challenges. The project is designed to provide continuous, timeless and boundless communication between project coordinators and students, students and their supervisors, as well as students researching in the same field. The project automates routine project activities such as listing and selection of project topics, approval of project topics, project report writing guidelines, student/supervisor correspondence, assessment and report submission, and finally report storage and management. Thus, it will eliminate the duplication and recycling of existing projects by making sure that such projects are rejected automatically at the very point of submission for approval, as well as guarantee high quality and timely completion and submission of students' projects. Agile software design approach, due to its high degree of stakeholder involvement and incremental testing of functionalities, was deployed to design the project. Also the system was developed using Java programming language with Apache Tomcat Server and MySQL as the Database Management System.
\end{abstract}

KEYWORDS: Final Year Project, Online Communication, Project Management, Project Supervision, Research Writing

\section{INTRODUCTION}

The Oxford English Dictionary defines project as: (i) an individual or collaborative enterprise that is carefully planned to achieve a particular aim (ii) a piece of research work undertaken by a school or college student (iii) a proposed or planned undertaking [1]. Further, Safieddine, views final year project as a demonstration of students' ability to integrate the knowledge they acquired from more than one course and subject, to produce a final work that shows their readiness to graduate [2]. Also Kamarudin states that a final year project entails students researching on a topic of their choice, engaging with the scholarly debates in the relevant disciplines, and, with a supervisor's guidance — producing a paper that reflects a deep understanding of the topic. He goes further to state that all undergraduates are required to complete their projects individually as part of the requirement to graduate. According to him still, project is where students develop a deeper understanding of the topic that is of interest to them. In his own words: "Students get a chance to interact with companies concerning their topic for data collection - whether it be observations, interviews, surveys or any other methods. It is also where they gain confidence and be more sure about themselves. I have seen shy students bloom in the final presentation and I could not be prouder [3]."

The National Board for Technical Education (NBTE) Curriculum, requires every student at his/her final year in both National Diploma (ND) and Higher National Diploma (HND) to carry out a project before graduating [4]. The School of Science of Akanu Ibiam Federal Polytechnic Unwana (AIFPU) is used as case study for this research project; and in the school, project is normally a second semester work with a timeframe of about 14 weeks while the $15^{\text {th }}$ week is used for its presentation or defense. Within the first week of the 14 weeks, every student is assigned a Supervisor who guides the student throughout the project. A number of students can be assigned to a supervisor and a number of students can be grouped together to undertake a single project depending on its level of difficulty or demands.

According to UCL Education Strategy, successful research needs good supervision. Typically, a supervisor acts as a guide, mentor, source of information and facilitator to the students as they progress through a research project [5]. In summary, therefore, the duty of a project supervisor is to guide the students allocated to him/her to conduct the research and report the findings appropriately. In the school of Science, AIFPU, supervision usually begins with the supervisor approving a project topic out of the three topics which a student is required to submit for consideration and approval. Every approved project topic is usually registered with a 


\section{International Journal of Current Science Research and Review}

ISSN: 2581-8341

Volume 04 Issue 12 December 2021

DOI: 10.47191/ijcsrr/V4-i12-05, Impact Factor: 5.825

IJCSRR@ 2021

www.ijcsrr.org

project coordinator who represents the department to organize, harmonize and manage the topics to ensure that the approved topics are not repeated or recycled. Once a topic has been approved and registered, the research work takes off forthwith.

\section{AIM AND OBJECTIVES}

Prior to this research, most of the processes and activities involved in students' final year projects, were completely carried out manually and relied heavily on traditional methods for communication, assessment, submission and management of finished projects. These, undoubtedly, often resulted in poor quality projects, duplication or recycling of existing projects, prolonged report writing, untimely submission of finished projects, and unstructured and poor management of project works. The aim of this research, therefore, is to provide remedy to these challenges using School of Science, AIFPU, as case study. The aim will be achieved through the design and implementation of a fully functional Web-based Student Project Management System which will provide continuous, timeless and boundless communication between project coordinators and students, students and their supervisors, as well as students researching in the same field. The project automates routine project activities such as listing and selection of project topics, approval of project topics, project report writing guidelines, student/supervisor correspondence, assessment and report submission and management. Thus, it will eliminate the duplication and recycling of existing projects by making sure that such projects are rejected automatically at the very point of submission for approval, as well as guarantee high quality and timely completion and submission of students' projects.

\section{LITERATURE REVIEW}

The Web-based Student Project Management System (WSPMS), School of Science, Akanu Ibiam Federal Polytechnic Unwana, is similar to a typical course management system (CMS), or a project management system (PMS). The comprehensive comparisons of CMS had been made by various parties like Unal [6] and Bremer [7], especially the two commonly employed systems: Moodle [8] and Blackboard [9].

ClockingIT [10] is a general PMS with free licensing. It provides basic management functions like task management with priority assignment to tasks, so that a project manager can better arrange manpower and plan the schedule of projects. Moreover, it has chat function and forum for ease of communication. At the same time, it provides functionalities to share folders for user to access documents and source code simultaneously. This system also includes some advanced functions like Gantt chart generator which is a standard tool for project scheduling.

Clement and Bounds shared similar goals as WSPMS in facilitating the management of final year projects [11]. Their system focuses on better ways to connect students with potential supervisors before the project allocation starts, and also includes tools for assessment submission and collection which are normal functions in a CMS.

Bakar et. al. reported their experience in developing and using final year project management system at Universiti Kebangsaan Malaysia [12]. Their system consists of three major modules which include: user profile, project monitoring and appointment setting modules. WSPMS contains similar functionalities and also incorporates additional modules like project allocation, file repository and online communication.

HKU CS Project Management System is a project management system developed in the University of Hong Kong, Department of Computer Science. The system can show project information, news, schedules and project allocation. In its main page, the system offers functions such as blogs, calendar and form downloading [13]. Also, there is a list of projects and related information, as well as some advanced functions such as providing a virtual machine for students as servers for their final year projects.

\section{SYSTEM OVERVIEW}

Agile software design approach, due to its high degree of stakeholder involvement and incremental testing of functionalities, was deployed to design the project. Also the system was developed using Java programming language with Apache Tomcat Server and MySQL as the Database Management System.

Based on functionalities, Web-based Student Project Management System (WSPMS) is divided into five modules (Figure 1). The modules include: project allocation module, communication module, project management module, file sharing and repository module, and submission and grading module. These modules are useful for servicing the needs of the different participants involved in the execution of the students' final year projects: Project Coordinator, Supervisors, and Students. 


\section{International Journal of Current Science Research and Review}

ISSN: 2581-8341

Volume 04 Issue 12 December 2021

DOI: 10.47191/ijcsrr/V4-i12-05, Impact Factor: 5.825

IJCSRR@ 2021

www.ijjesrr.org

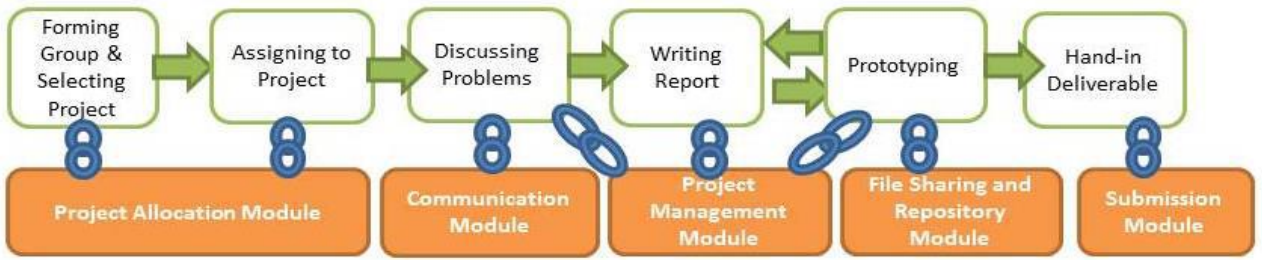

Figure 1: Overview of the System Modules and Functionalities

Before the beginning of the second semester of a session, the Project Coordinator will use the project allocation module to create all users' accounts and make it ready for all users. He will then, by the automatic allocation function provided by the module, allocate students to supervisors in a systematic manner starting from the first student and ending with the last student on the students' list, and also in the order of rank of the supervisors starting with the head of the department (HOD). On the completion of the allocation, the system, will publish the project allocation list thereby notifying all the parties involved.

At the beginning of the second semester, the students use the system to submit and get project topics approved for them by their supervisors as the system supports functions such as task management, file sharing, and instant chat and discussion. As the project topics are approved, the system takes record and incrementally, publishes the listing. From then on, the research and supervision take off. At the end of the whole exercise, the students will upload their deliverables and will be scheduled for defense. After defense and grading of the students, the scores are uploaded and ultimately published. The system hosts and manages the different deliverables of the process.

\section{SYSTEM FUNCTIONALITIES AND IMPLEMENTATION}

\section{A. Project Allocation and Communication Modules}

Project coordinator would normally use pen and paper to allocate students to supervisors. This is usually cumbersome and error prone. With WSPMS, the process is automated. He uses the admins's dashboard to carry out the allocation automatically by giving appropriate instructions in the system. At the end of the allocation, the system publishes the list through the communication module. Figure 2 depicts the use case of the student project allocation module.

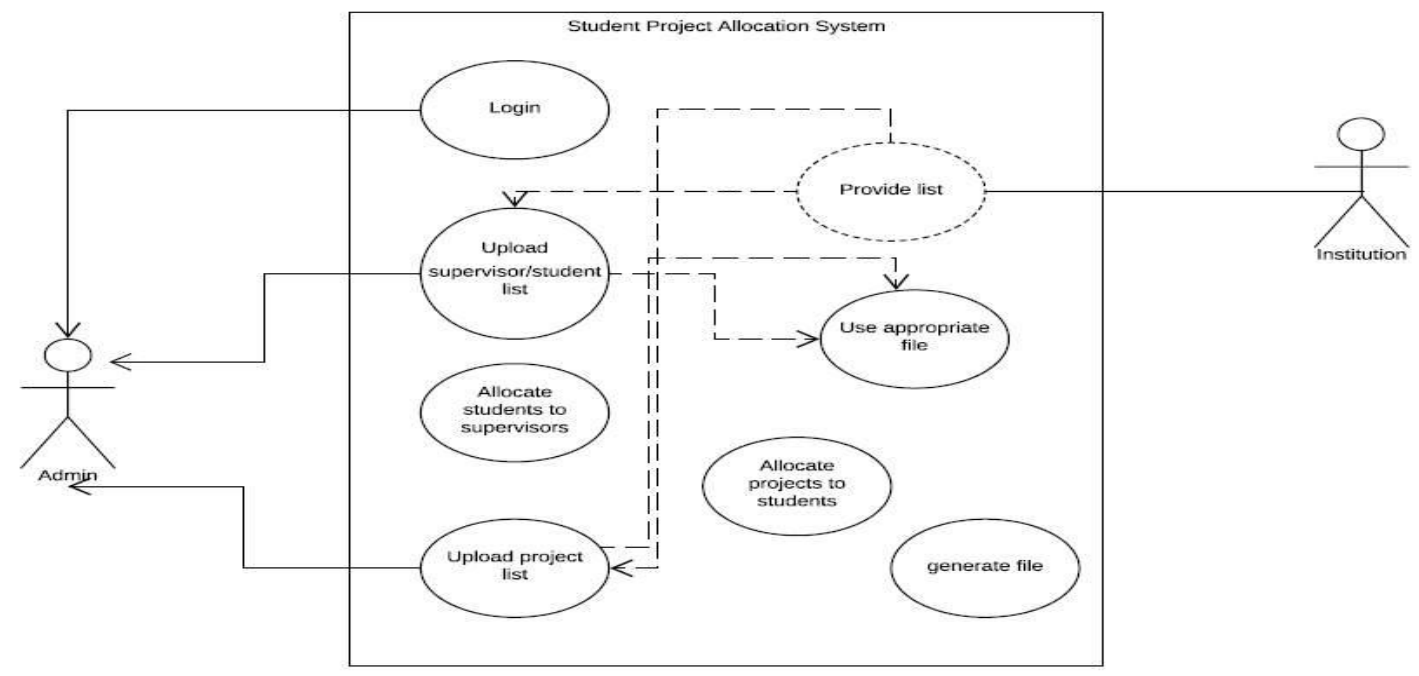

Figure 2: Project Allocation Module Use Case Diagram

The communication is responsible for the publication of the allocation list after project allocation has been carried out. It is also the module the students deploy to submit and get project topics approved for them by their supervisors as the module supports functions such as task management, file sharing, and instant chat and discussion. 


\section{International Journal of Current Science Research and Review}

ISSN: 2581-8341

Volume 04 Issue 12 December 2021

DOI: 10.47191/ijcsrr/V4-i12-05, Impact Factor: 5.825

IJCSRR@ 2021

www.ijcsrr.org

\section{B. Project Management Module}

Apart from the communication issues, it is essential for all members to have a clear target or goal to accomplish during the development of the project. As both students and supervisors are always busy on the course works, teaching and learning during the semester, in order to keep up the momentum of working on the project, project management tool is useful.

Our current project management module includes a task management tool to help students in keeping their schedule. Students can create and edit tasks on their scheduler by directly selecting the deadlines as in Figure 3. Each task in this TODO list can be assigned with a priority to help students sorting out the completion order of their tasks in hand. It is also very useful in facilitating the discussion and progress checking in the regular meeting between supervisor and students.

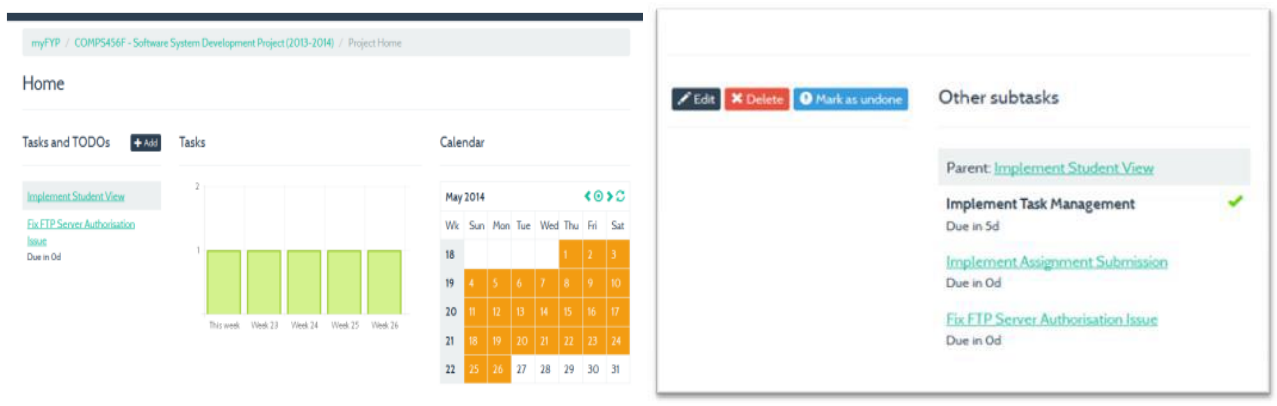

Figure 3: Task Management System Module

Using this module, student can create tasks on the scheduler and plan for a reasonable completion date of project milestones. Therefore, students can keep track of their progress more easily.

\section{File Sharing and Repository Module}

File sharing and repository module provides a web interface for uploading, storing and sharing of project related resources like source code, documents, images, etc. This file repository provides a more secure and centralized space for students to keep their produced works. A supervisor can easily access a student's work and keep track of the progress by directly viewing the shared deliverable of the project. Figure 4 displays the web interface when accessing the repository, only the owner of the project together with the supervisor will be able to access the files in the repository and share among themselves.

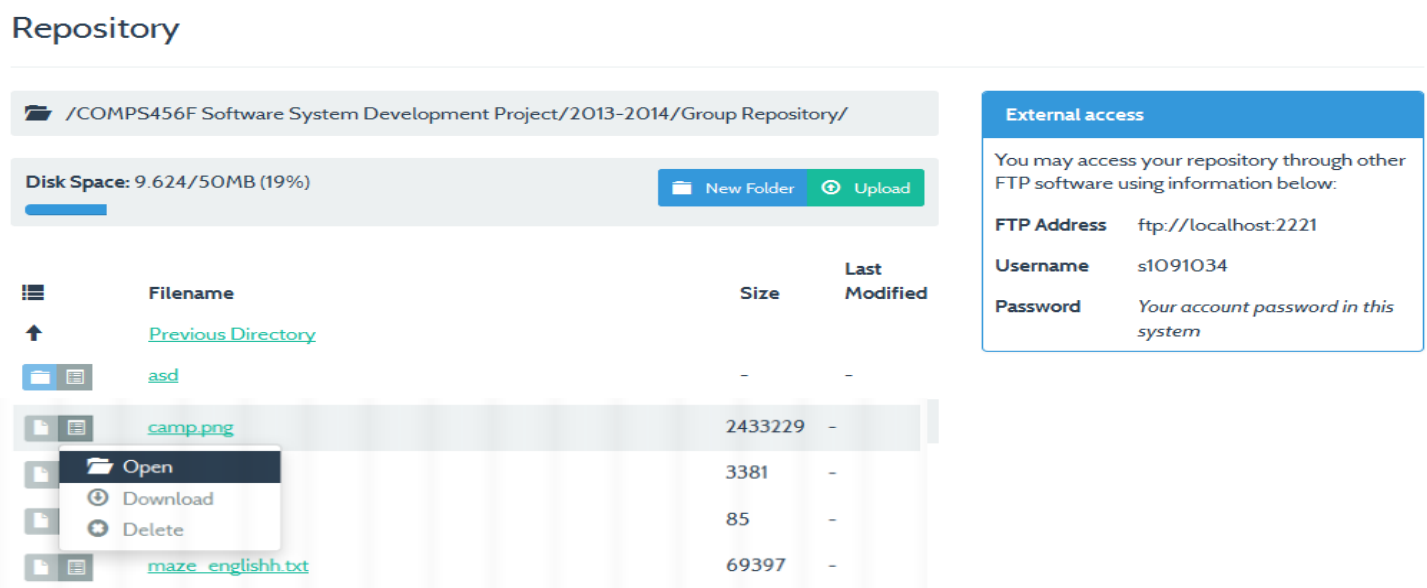

Figure 4: System's Repository Interface

\section{Submission and Grading Module}

At the end of the $14^{\text {th }}$ week allotted for project, students are expected to turn in their reports. Instead of sending in physical copies to the department for assessment, the system provides a submission and grading module which allows them to do this online (Figure 5). The department can easily check all the submissions and obtain all the deliverables by simply downloading from the system. 


\section{International Journal of Current Science Research and Review}

ISSN: 2581-8341

Volume 04 Issue 12 December 2021

DOI: 10.47191/ijesrr/V4-i12-05, Impact Factor: 5.825

IJCSRR@ 2021

www.ijjesrr.org

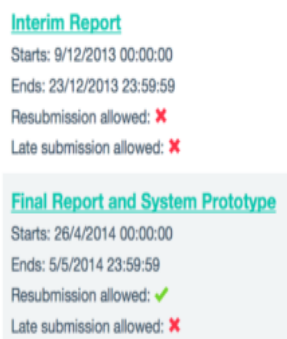

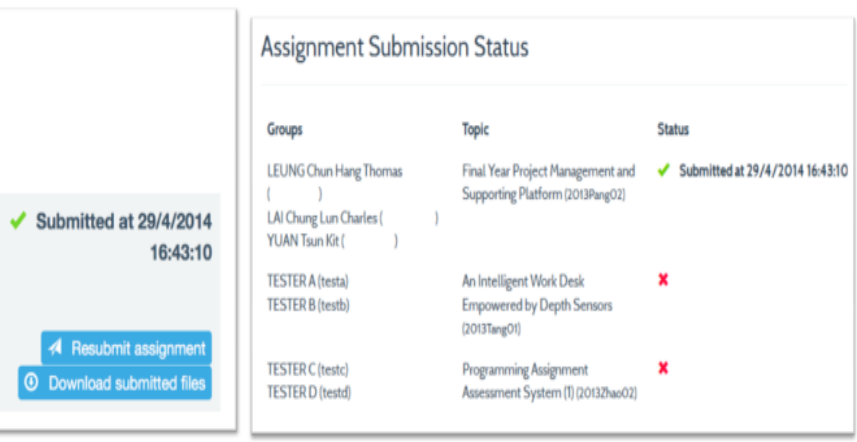

Figure 5: Project Submission and Repository Module Interface

Apart from relieving the workload of collecting physical documents and deliverables, assessors can easily download the report, review and provide score all through the system via the interface provided by the module (Figure 6).

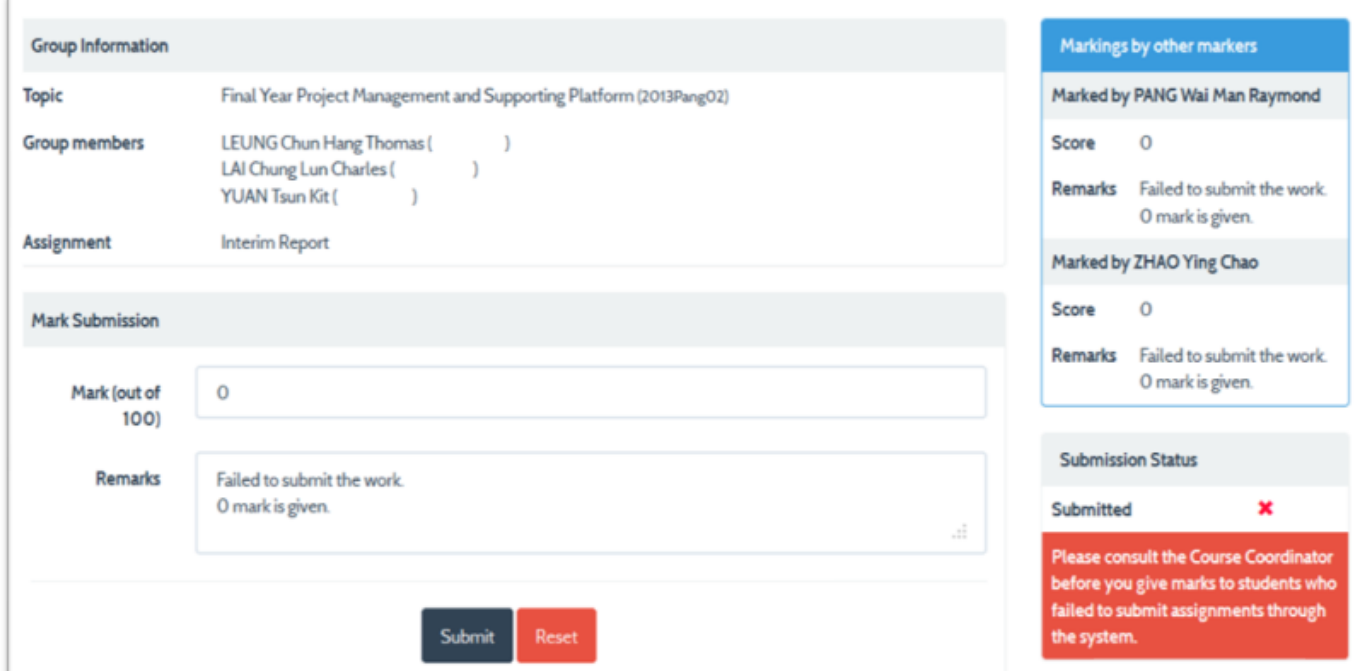

Figure 6: Assessor's System Interface

\section{PRELIMINARY USER STUDY AND EVALUATION OF THE SYSTEM}

To better understand the strength and weakness of our system, we have performed a preliminary study by interviewing thirteen students who are in their third or fourth year's study. They are asked to try using all modules of the system, and then complete a questionnaire after the trial. The 10 questions are all yes or no questions. Some of these questions and the response are shown in Figure 7.
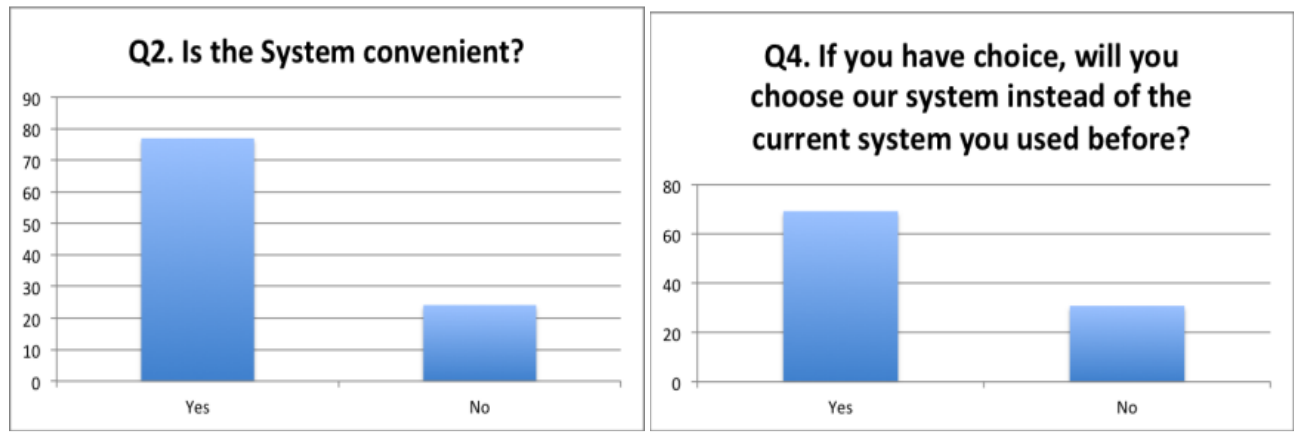


\section{International Journal of Current Science Research and Review}

ISSN: 2581-8341

Volume 04 Issue 12 December 2021

DOI: 10.47191/ijesrr/V4-i12-05, Impact Factor: 5.825

IJCSRR @ 2021

www.ijesrr.org

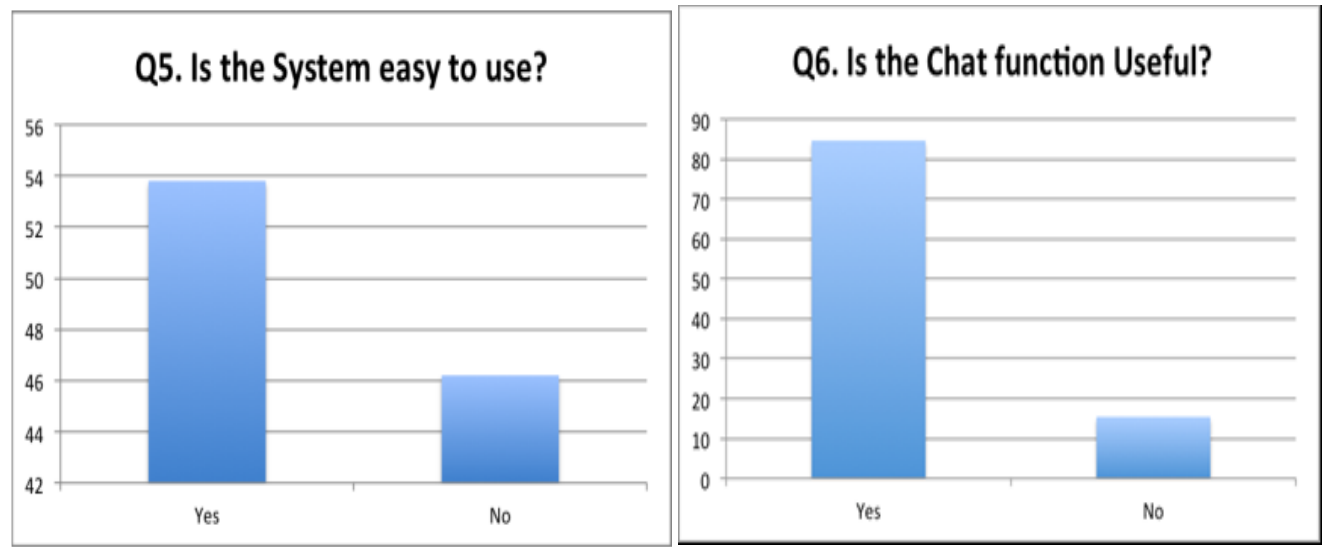

Figure 7: Questionnaire Result Bar chart

Most of the responses are positive to our system, including the ease-of-use of the system and certain functions. Also, over 70 percent of the users thinks the system is convenient and willing to switch to the system.

\section{CONCLUSION}

The Web-based Student Project Management System (WSPMS) is designed to facilitate the implementation of the final year project in the School of Science, Akanu Ibiam Federal Polytechnic Unwana. The WSPMS management system can significantly reduce the workload of the project coordinator. The tasks of arrangement, announcement, collection and assessment can be done automatically using the system. On the other hand, the system provides convenience for both supervisors and students throughout the process of final year project. First, supervisors and students can better communicate via the chat and messaging tools in the system. Supervisors can also easily keep track of the progress of students with the project management module and file sharing functions. Finally, supervisors and assessors can quickly obtain the deliverables of the project and provide grades using the system. We strongly recommend the implementation and deployment of WSPMS in the school.

\section{REFERENCES}

1. Oxford. (n.d.). Project. In Oxford English.com dictionary. Retrieved September 12, 2021 from https://www.oxford.com/dictionary/project

2. Safieddine, F. (2015) Student's guide: final year project thesis. (K.Lomidze, Ed) New York: CreativeSpace Publishing.

3. Kamarudin D. (2019). Applying skills and knowledge in final year projects. New Straits Tmes

4. Oxford English Dictionaries (2021). Retrieved 05/03/2021.

5. National Board for Technical Education (NBTE) Curriculum. (2019, April 21).

6. UCL Education Strategy (2019). Research and project supervision (all levels): an introduction. Retrieved September 25, 2021 from https://www.ucl.ac.uk

7. Unal, Z., and Unal, A. (2011). Evaluating and comparing the usability of web-based course management systems. Journal of Information Technology Education, 10, 19-38 View publication

8. Bremer, D, Bryant, R. (2005) A Comparison of two learning management Systems: Moodle vs Blackboard, Proceedings of the 18

9. Dougiamas, M. \& Taylor, P. C. (2003). Moodle: Using learning communities to create an open source course management system. Proceedings of the EDMEDIA 2003 Conference, Honolulu, Hawaii, .Blackboard Inc. (2013) "Blackboard", URL: http://www.blackboard.com/.

10. ClockingIT.com (2008). ClockingIT free time-tracking hosting, URL: http://www.clockingit.com/

11. Clement R. \& Bounds P. (2013). Making Connections between Final Year Students and Potential Project Supervisors, Proceedings of the HEA STEM Learning and Teaching Conference. 


\section{International Journal of Current Science Research and Review}

ISSN: 2581-8341

Volume 04 Issue 12 December 2021

DOI: 10.47191/ijcsrr/V4-i12-05, Impact Factor: 5.825

IJCSRR@ 2021

www.ijesrr.org

12. Bakar M. A., Jailani N., Shukur Z., Yatim N. F. M. (2011). Final Year Supervision Management System as a Tool for Monitoring Computer Science Projects. Procedia Social and Behavioral Sciences 18, 273-281

13. HKU CS (2014). Hong Kong University Project Management System, URL: https://community.cs.hku.hk/web/csis0801/

Cite this Article: Ugboaja Uchenna Chikwendu, Eziechina Malachy Amaechi (2021). Web-Based Student Project Management System: A Tetfund Institution-Based Research Report. International Journal of Current Science Research and Review, 4(12), 1645-1651 